\title{
Kecernaan Nutrien Ternak Sapi Bali yang Diberi Pakan Dasar Rumput Panah dan Daun Angsana Disuplementasi Daun Sengon (Paraserianthes falcataria L.)
}

Jefridus Bria Seran ${ }^{\mathrm{a}}$

${ }^{a}$ Fakultas Pertanian, Universitas Timor, Kefamenanu, TTU - NTT, Indonesia.

\section{Article Info}

\section{Article history:}

Received 10 Agustus 2017

Received in revised form 15 September 2018 Accepted 2 Oktober 2018

DOI:

https://doi.org/10.32938/ja.v3i4.365

Keywords:

Kecernaan Nutrien

Sapi Bali

Rumput Panah

Angsana

Sengon Laut

\section{Abstrak}

Penelitian ini dilaksanakan di Kelompok Tani-Ternak Ulnaet Tuan, Desa Letmafo, Kecamatan Insana Tengah, Kabupaten TTU selama 3 bulan yakni bulan April - Juni 2017, dengan tujuan untuk mengetahui kecernaan nutrien ransum ternak sapi bali yang diberi pakan dasar rumput panah dan daun angsana disuplementasi daun sengon (Paraserianthes falcataria L.). Penelitian menggunakan rancangan acak kelompok (RAK) yang terdiri atas 4 perlakuan ransum dan 3 kelompok berat badan ternak sebagai ulangan. Sapi yang digunakan sebanyak 12 ekor dengan berat badan rata-rata kelompok $\mathrm{I}=84,75 \mathrm{~kg}$, kelompok $\mathrm{II}=137,25 \mathrm{~kg}$ dan kelompok III $=164,25 \mathrm{~kg}$. Keempat perlakuan ransum yang digunakan adalah: A). $80 \%$ rumput panah $+20 \%$ daun angsana (Kontrol), B). $80 \%$ rumput panah $+20 \%$ daun angsana $+10 \%$ daun sengon, C). $80 \%$ rumput panah $+20 \%$ daun angsana $+15 \%$ daun sengon, dan D). $80 \%$ rumput panah $+20 \%$ daun angsana $+20 \%$ daun sengon. Hasil penelitian menunjukkan bahwa pemberian daun sengon hingga $20 \%$ dalam ransum dasar rumput panah dan daun angsana mampu meningkatkan kecernaan nutrien, sehingga bakteri optimal meningkatkan pemanfaatan pakan dan menyebabkan pertambahan berat badan Sapi Bali menjadi tinggi. Untuk mendapatkan tingkat kecernaan nutrien sapi bali jantan yang baik maka disarankan pemberian pakan dasar rumput panah $80 \%$ dan daun angsana $20 \%$ perlu disuplementasi dengan daun sengon laut sebesar $20 \%$

\section{Pendahuluan}

Sapi Bali merupakan komoditi unggulan di Nusa Tenggara Timur (NTT) dan juga sebagai pemasok protein hewani yang baik. Ditinjau dari karakteristik karkas dan bentuk badan yang kompak dan serasi, sapi bali digolongkan sebagai sapi pedaging ideal, bahkan nilai mutu dagingnya lebih unggul dari pada sap pedaging Eropa seperti Hereford dan Shortorn. Sapi bali mempunyai keunggulan tahan hidup pada lingkungan yang kurang memadai misalnya tanpa dikandangkan (tahan panas dan hujan), dan di tempat yang rendah kualitas pakannya walaupun ada penurunan produksi dan reproduksi (Toliehere, 2003) Kualitas produksi daging sapi bali tergantung pada pertumbuhannya karena produksi yang tinggi dapat dicapai dengan pertumbuhan yang cepat (Sampurna \& Suatha, 2010). Ada beberapa kendala yang dialami oleh peternak dalam beternak sapi bali, diantaranya permasalahan pakan dan nutrisi (Deptan, 2001).

Pakan utama bagi ternak ruminansia adalah hijauan khususnya rumput sehingga ketersediaan pakan hijauan baik kuantitas maupun kualitas yang berkesinambungan sepanjang tahun merupakan salah satu faktor penting untuk meningkatkan produksi ternak. Di NTT rumput alam merupakan pakan utama ternak sapi bali yang ketersediaannya sangat berfluktuasi mengikuti musim dan umumnya berkualitas rendah, terutama pada musim kemarau, sehingga sanga mempengaruhi produktivitas ternak. Rendahnya kecernaan zat-zat makanan rumput alam akibat tingginya serat neutral detergent fiber (NDF) dengan kandungan protein kasar yang rendah membatasi aktivitas dan pertumbuhan mikroorganisme rumen karena kurangnya zat-zat makanan yang dapat dimanfaatkan oleh mikroba rumen tersebut

Pencernaan fermentatif di dalam rumen pada ternak ruminansia pada dasarnya ditentukan oleh faktor internal, eksternal, dan interaksi keduanya Faktor internal tersebut ditekankan pada kapasitas rumen $( \pm 70 \%)$ dar keseluruhan kapasitas saluran pencernaan dan juga ekosistem rumen serta aktivitas mikroba rumen itu sendiri (Orskov \& Ryle, 1990). Faktor eksternal yang dimaksud adalah jenis pakan yang diberikan pada ternak ruminansia, baik yang berhubungan dengan sifat fisik, kemis, dan biologis yang nantinya dapa berpengaruh terhadap aktivitas mikroba rumen mendegradasi pakan. Dalam ha ini, pencernaan pakan secara fermentatif, baik bahan kering atau pun bahan organik yang terdegradasi semakin tinggi sejalan dengan lamanya proses fermentasi berlangsung. Kondisi fisiologis ini menunjukkan bahwa pada waktu yang bersamaan aktivitas mikroba rumen mendegradasi pakan semakin meningkat, sehingga produk fermentasi juga semakin tinggi. Waktu fermentas (inkubasi) dalam rumen 3-4 jam setelah ternak diberi makan dapat dijadikan sebagai patokan dalam menentukan pertumbuhan dan aktivitas mikroba rumen dengan mengukur produksi biomassa sintesis protein mikroba (Sutardi, 1995).

Bahan pakan yang umum digunakan sebagai suplementasi penggunaan ransum berbasis rumput alam yaitu leguminosa pohon, seperti gamal dan lamtoro yang sering digunakan oleh peternak. Hal tersebut dikarenakan leguminosa pohon memiliki kandungan nutrien yang cukup baik khususnya protein. Selain itu tingginya kandungan serat menyebabkan gamal dan lamtoro cocok digunakan sebagai sumber hijauan untuk ternak ruminansia. Selain itu penambahan lamtoro dan gamal dapat meningkatkan kecernaan bahan organik pakan, seperti yang dinyatakan oleh Putri \& Marsetyo (2006), bahwa penambahan lamtoro dan gamal pada domba yang mendapatkan pakan dasar jerami jagung dapat meningkatkan kecernaan bahan organik pakan.

Sehubungan dengan itu, dalam upaya meningkatkan kemampuan mikroba rumen mendegradasi pakan, sudah selayaknya memperhatikan jenis pakan dasa dan kandungan nutriennya, agar dapat memenuhi mikroba rumen akan VFA dan amonia. Salah satu pakan yang dapat dijadikan sebagai sumber protein mudah terdegradasi adalah daun gamal (Gliricidia sepium), 66\% dari total protein yang dikandungnya dapat memacu sintesis protein tubuh mikroba (Sutardi, 1995). Pakan rumput alam dapat menghasilkan VFA yang nantinya dimanfaatkan sebagai sumber energi, baik oleh mikroba rumen ataupun hewan inang. Rumput panah pada musim hujan memiliki protein kasar tinggi (Kaho, 2012), namun pada musim panas/kemarau memiliki kandungan protein rendah hanya 5,90\% (Sio, 2016). Pakan lain yang dapat diandalkan sebagai sumber protein mudah terdegradasi adalah sengon. Sengon merupakan salah satu leguminosa pohon yang tumbuh subur pada musim panas maupun hujan. Selain itu daun sengon memiliki kandungan protein tinggi yakni $10 \%$ (Sio, 2016). Namun disisi lain pemanfaatan daun sengon sebagai pakan hijauan untuk sapi bali di NTT umumnya belum dilakukan secara optimal.

\section{Metode}

Penelitian ini telah dilaksanakan di Kelompok Tani-Ternak Ulnaet Tuan, Desa Letmafo, Kecamatan Insana Tengah, Kabupaten TTU. Waktu yang diperlukan untuk pelaksanaan penelitian adalah 3 bulan. Alat yang digunakan pada penelitian ini berupa: timbangan elektronik merek sonic-scale (A12E), timbangan gantung berkapasitas $50 \mathrm{~kg}$, timbangan duduk, sabit, pisau, parang, ember, kandang jepit, sekop, karung, buku tulis dan bolpoin.

Penelitian ini menggunakan Rancangan Acak Kelompok (RAK) yang terdiri atas 4 perlakuan ransum dengan 3 kelompok berat badan ternak sebagai ulangan, sehingga sapi yang digunakan berjumlah 12 ekor. Sapi yang digunakan adalah sapi bali penggemukan dengan berat badan rata-rata kelompok $\mathrm{I}=84,75$ $\mathrm{kg}$, kelompok II $=137,25 \mathrm{~kg}$ dan kelompok $\mathrm{III}=164,25 \mathrm{~kg}$. Keempat perlakuan ransum yang digunakan adalah:

A. $80 \%$ rumput panah $+20 \%$ daun angsana (kontrol)

B. $80 \%$ rumput panah $+20 \%$ daun angsana $+10 \%$ daun sengon

C. $80 \%$ rumput panah $+20 \%$ daun angsana $+15 \%$ daun sengon

D. $80 \%$ rumput panah $+20 \%$ daun angsana $+20 \%$ daun sengon

Komposisi kimia dari pakan yang digunakan dalam penelitian tercantum pada Tabel 1

Tabel 1. Hasil Analisis Proksimat dari Pakan yang Digunakan dalam Penelitian

\begin{tabular}{|c|c|c|c|c|c|c|c|c|c|}
\hline \multirow[b]{2}{*}{$\begin{array}{l}\text { Bahan } \\
\text { Pakan }\end{array}$} & \multirow[b]{2}{*}{$\begin{array}{l}\mathrm{BK} \\
(\%)\end{array}$} & \multirow[b]{2}{*}{$\begin{array}{c}\mathrm{BO} \\
(\% \mathrm{BK})\end{array}$} & \multirow[b]{2}{*}{$\begin{array}{c}\text { PK } \\
(\% \mathrm{BK})\end{array}$} & \multirow[b]{2}{*}{$\begin{array}{c}\mathrm{LK} \\
\text { (\%BK) }\end{array}$} & \multirow[b]{2}{*}{$\begin{array}{l}\mathrm{CHO} \\
(\% \mathrm{BK}\end{array}$} & \multicolumn{3}{|c|}{ Gross Energi } & \multirow[b]{2}{*}{$\begin{array}{c}\mathrm{EM} \mathrm{KKal} / \mathrm{Kg} \\
\mathrm{BK}\end{array}$} \\
\hline & & & & & & (\%Bk) & $\begin{array}{c}\mathrm{MJ} / \mathrm{Kg} \\
\mathrm{BK}\end{array}$ & $\begin{array}{c}\mathrm{KKal} / \mathrm{Kg} \\
\mathrm{BK}\end{array}$ & \\
\hline$n$ & 89,24 & 88,84 & 8,15 & 4,11 & 7,58 & 45,92 & 16,63 & $3,958,37$ & $2,633,21$ \\
\hline & 88,20 & 94,18 & 20,68 & 7,47 & 66,03 & 54,97 & 18,98 & $4.519,91$ & $3.775,46$ \\
\hline & 86,67 & 90,40 & 9,56 & 6,56 & 72,27 & 52,24 & 17,55 & $4.177,61$ & $3.237,34$ \\
\hline
\end{tabular}

Keterangan: BK: Bahan Kering; PK: Protein Kasar; LK: Lemak Kasar; SK Serak Kasar CHO: Karbohidrat; BETN: Bahan Ekstrak Tanpa Nitrogen; EM: Energi Metabolisme

Pengambilan sampel dilakukan selama 7 hari, pada minggu terakhir penelitian. Sampel yang diambil adalah: feses, rumput panah, daun angsana, daun sengon dan sisa rumput panah, daun angsana dan daun sengon. Rumput panah, daun sengon serta sisa rumput panah dan daun sengon masing-masing diambil $200 \mathrm{~g}$ setiap hari. Pada akhir pengambilan total dicampur dan dikomposit sesuai dengan ternaknya. Setelah dicampur diambil $200 \mathrm{~g}$ untuk dianalisis di Laboratorium. Pengambilan feses dapat dilakukan sebagai berikut: Feses yang dikeluarkan selama 24 jam dikumpulkan dan ditimbang untuk diketahui beratnya. Selanjutnya feses diambil $200 \mathrm{~g}$ dan dikeringkan dengan matahari. Pada akhir pengambilan total feses dicampur dan dikomposit sesuai ternak, kemudian feses masing-masing ternak diambil $200 \mathrm{~g}$ untuk analisa laboratorium.

Sampel ransum dan feses dianalisis proksimat yaitu bahan kering (BK), bahan organik (BO), protein kasar (PK), serat kasar (SK) dan kandungan energi bruto (GE). Sedangkan sisa ransum hanya dilakukan analisis bahan kering (BK) Data ini akan digunakan untuk menghitung kecernaan bahan kering $(\mathrm{KcBK})$ dan kecernaan nutrien ransum (protein kasar, bahan organik, serat kasar, lemak kasar). 
Data yang diperoleh dari penelitian ini akan dianalisis dengan analisis sidik ragam (Anova) Rancangan Acak Kelompok (RAK). Bila terdapat perlakuan yang berbeda nyata $(\mathrm{P}<0,05)$, maka analisis dilanjutkan dengan uji jarak berganda Duncan pada taraf $\alpha 5 \%$ (Steel \& Torrie, 1986).

\section{Hasil dan Pembahasan}

\subsection{Kecernaan Bahan Kering dan Nutrien Ransum}

Kecernaan merupakan persentase nutrien yang diserap dalam saluran pencernaan yang hasilnya akan diketahui dengan melihat selisih antara jumlah nutrien yang dimakan dan jumlah nutrien yang dikeluarkan dan yang terkandung dalam feses. Kecernaan juga merupakan indikator pengukuran kinerja pakan. Rerata kecernaan Bahan Kering (BK), Protein Kasar (PK), Serat Kasar (SK) dan Bahan Organik (BO) ternak Sapi Bali yang mendapat perlakuan pakan seperti terlihat pada Tabel 2.

Tabel 2. Kecernaan Nutrien Sapi Bali yang Diberi Pakan Dasar Rumput Panah dan Daun Angsana Disuplemtasi Daun Sengon

\begin{tabular}{lcccc}
\hline \multirow{2}{*}{ Variabel } & \multicolumn{4}{c}{ Perlakuan } \\
\cline { 2 - 5 } & $\mathrm{A}$ & $\mathrm{B}$ & $\mathrm{C}$ & $\mathrm{D}$ \\
\hline Bahan Kering (\%) & 64 & 52 & 38 & 28 \\
Protein Kasar (\%) & $30^{\mathrm{b}}$ & $63^{\mathrm{ab}}$ & $71^{\mathrm{b}}$ & $82^{\mathrm{a}}$ \\
Serat Kasar (\%) & $30,23^{\mathrm{b}}$ & $43^{\mathrm{b}}$ & $58,3^{\mathrm{b}}$ & $69^{\mathrm{a}}$ \\
Bahan Organik (\%) & $45^{\mathrm{b}}$ & $65^{\mathrm{b}}$ & $72^{\mathrm{a}}$ & $78^{\mathrm{a}}$ \\
\hline Keterangan: Nilai dengan superskrip yang berbeda dalam baris yang sama adalah berbeda \\
nyata (P<0.05)
\end{tabular}

Kecernaan bahan kering (BK) sapi bali yang mendapat ransum A adalah: $64 \%$. Kecernaan bahan kering pada Sapi yang mendapat ransum B, C dan D berturut-turut adalah: $52 \%, 38 \%$ dan $28 \%$. Hasil penelitian menunjukkan kecernaan bahan kering pada perlakuan yang mendapat suplementasi daun sengon laut $(B, C$ dan $D)$ berbeda nyata $(P<0.05)$ dibanding dengan perlakuan yang tidak mendapat daun sengon laut (A). Hasil uji berganda Duncan menunjukkan bahwa terdapat perbedaan nyata antara perlakuan A dengan perlakuan B, C dan D. Perlakuan B berbeda nyata dengan C dan D, begitu pula perlakuan $\mathrm{C}$ dan $\mathrm{D}$. Kecernaan bahan kering tertinggi pada perlakuan D yaitu $28 \%$, hal ini karena kandungan protein kasar perlakuan D tinggi. Rata-rata kecernaan protein kasar sapi bali yang mendapat ransum A adalah: $30 \%$, dan sapi yang mendapat ransum $\mathrm{B}, \mathrm{C}$ dan $\mathrm{D}$ masing-masing adalah : $63 \%, 71 \%$ dan $82 \%$. Hasil uji lanjut Duncan menunjukkan kecernaan protein pada perlakuan yang mendapat daun sengon berbeda nyata dibanding dengan perlakuan A. Perlakuan $\mathrm{B}$ dengan $\mathrm{C}$ secara statistik tidak nyata, namun dengan $\mathrm{D}$ berbeda nyata $(\mathrm{P}<0,05)$ meningkatkan kecernaan protein kasar. Perlakuan $\mathrm{C}$ dengan $\mathrm{D}$, secara statistik nyata $(\mathrm{P}<0,05)$. Kecernaan protein kasar tertinggi pada perlakuan $\mathrm{D}$ yaitu $82 \%$. Hal ini mengindikasikan bahwa ransum pada perlakuan D memiliki kandungan protein kasar yang lebih baik dimana menurut (Khoerunnisa,2006), kecernaan protein bahan makanan tergantung pada kandungan protein ransum. Bahan makanan yang rendah kandungan proteinnya mempunyai kecernaan protein yang rendah, begitu pula sebaliknya. Selain itu, kecernaan protein dapat tertekan dengan meningkatnya kadar serat kasar ransum.

Rata-rata kecernaan serat kasar pada sapi bali yang mendapat ransum A adalah $30,23 \%$. Kecernaan serat kasar sapi yang mendapat ransum B, C dan D berturut-turut adalah $43 \%, 58,3 \%$ dan $69 \%$. Hasil penelitian menunjukkan kecernaan serat kasar pada Sapi yang mendapat perlakuan dengan daun sengon berbeda nyata $(\mathrm{P}<0.05)$ meningkat dibanding dengan perlakuan A. Hasil uji lanjut berganda Duncan mengindikasikan bahwa terdapat perbedaan yang nyata antara perlakuan A dengan perlakuan B, C dan D. Perlakuan B dengan C dan D nyata, begitu pula $\mathrm{C}$ dengan $\mathrm{D}$. Kecernaan serat kasar tertinggi pada perlakuan $\mathrm{D}$ yakni $69 \%$. Tingginya kecernaan serat kasar pada perlakuan D, berkaitan dengan kandungan nutrien pakan yang tinggi terutama protein, sehingga menyebabkan populasi bakteri meningkat.

Rataan kecernaan bahan organik pada sapi bali yang mendapat ransum A adalah $45 \%$. Kecernaan bahan organik pada sapi yang mendapat ransum B, C dan D masing-masing adalah: $65 \%, 72 \%$ dan $78 \%$. Hasil analisis sidik ragam menunjukkan kecernaan bahan organik pada perlakuan dengan daun sengon laut berbeda nyata $(\mathrm{P}<0.05)$ meningkat dibanding dengan perlakuan $\mathrm{A}$. Hasil uji lanjut Duncan menunjukkan kecernaan bahan organik pada perlakuan $\mathrm{B}, \mathrm{C}$ dan D secara statistik berbeda nyata $(\mathrm{P}<0,05)$ dibanding dengan perlakuan $\mathrm{A}$. Perlakuan B dengan $C$ dan $D$ berbeda nyata, namun perlakuan $C$ dengan $D$ tidak nyata. Kecernaan bahan organik tertinggi pada sapi yang mendapat ransum D yaitu $78 \%$. Meningkatnya kecernaan bahan organik pada penelitian ini berhubungan dengan penambahan daun sengon laut dalam ransum dasar menyebabkan aktivitas bakteri meningkat yang berdampak pada meningkatnya kecernaan bahan organik dan serapan nutrien untuk pertumbuhan, sehingga mendorong pula meningkatnya konsumsi dan kecernaan bahan organik.

Dengan demikian penambahan daun sengon laut pada ransum dasar mampu meningkatkan nutrien ransum, sehingga bakteri optimal meningkatkan pemanfaatan pakan. Bakteri akan bekerja lebih giat dalam mencerna pakan di dalam rumen, sehingga kecernaan pakan menjadi meningkat. Meningkatnya kecernaan pakan akan diikuti dengan tingginya kecernaan protein, yang berakibat pada meningkatnya pertumbuhan dan pertambahan berat badan harian sapi bali.

\subsection{Nutrien Tercerna}

Rerata protein tercerna sapi yang mendapat ransum A adalah $0,14 \mathrm{~kg} / \mathrm{e} / \mathrm{h}$. Sapi yang mendapat ransum B, C dan D masing-masing adalah 0,37 kg/e/h, 0,45 $\mathrm{kg} / \mathrm{e} / \mathrm{h}$ dan $0,55 \mathrm{~kg} / \mathrm{e} / \mathrm{h}$. Hasil analisis sidik ragam mengindikasikan ransum dengan daun sengon laut nyata $(\mathrm{P}<0,05)$ meningkatkan protein tercerna dibanding dengan perlakuan A. Hasil uji Duncan menunjukkan pada perlakuan $\mathrm{B}, \quad \mathrm{C}$ dan $\mathrm{D}$ nyata $(\mathrm{P}<0,05)$ meningkatkan protein tercerna dibanding dengan perlakuan A. Perlakuan B dengan C nyata, tetapi B dengan D tidak nyata Sedangkan perlakuan C dengan D tidak nyata. Rerata protein tercerna tertinggi pada sapi yang mendapat perlakuan ransum D yaitu $0,55 \mathrm{~kg} / \mathrm{e} / \mathrm{h}$ (Tabel 3.).

Tabel 3. Nutrien Tercerna Sapi Bali yang diberi pakan Dasar Rumput Panah dan Daun Angsana di Suplementasi Daun Sengon

\begin{tabular}{lcccc}
\hline \multirow{2}{*}{ Variabel } & \multicolumn{4}{c}{ Perlakuan } \\
\cline { 2 - 5 } & $\mathrm{A}$ & $\mathrm{B}$ & $\mathrm{C}$ & $\mathrm{D}$ \\
\hline Konsumsi PK $(\mathrm{kg} / \mathrm{e} / \mathrm{h})$ & $0,48^{\mathrm{b}}$ & $0,58^{\mathrm{b}}$ & $0,63^{\mathrm{b}}$ & $0,67^{\mathrm{a}}$ \\
Protein Feses $(\mathrm{kg} / \mathrm{e} / \mathrm{h})$ & $0,34^{\mathrm{a}}$ & $0,21^{\mathrm{b}}$ & $0,18^{\mathrm{ab}}$ & $0,12^{\mathrm{b}}$ \\
Protein Tercerna $(\mathrm{kg} / \mathrm{e} / \mathrm{h})$ & $0,14^{\mathrm{b}}$ & $0,37^{\mathrm{b}}$ & $0,45^{\mathrm{b}}$ & $0,55^{\mathrm{a}}$ \\
Konsumsi BO $(\mathrm{kg} / \mathrm{e} / \mathrm{h})$ & $4,65^{\mathrm{b}}$ & $5,44^{\mathrm{ab}}$ & $5,74^{\mathrm{a}}$ & $5,81^{\mathrm{a}}$ \\
BO Feses $(\mathrm{kg} / \mathrm{e} / \mathrm{h})$ & $2,54^{\mathrm{a}}$ & $1,92^{\mathrm{a}}$ & $1,61^{\mathrm{a}}$ & $1,26^{\mathrm{a}}$ \\
BO Tercerna $(\mathrm{kg} / \mathrm{e} / \mathrm{h})$ & $2,11^{\mathrm{b}}$ & $3,52^{\mathrm{b}}$ & $4,13^{\mathrm{b}}$ & $4,55^{\mathrm{a}}$ \\
Konsumsi SK $(\mathrm{kg} / \mathrm{e} / \mathrm{h})$ & $0,90^{\mathrm{b}}$ & $1,03^{\mathrm{a}}$ & $1,07^{\mathrm{a}}$ & $1,11^{\mathrm{a}}$ \\
SK Feses $(\mathrm{kg} / \mathrm{e} / \mathrm{h})$ & $0,60^{\mathrm{a}}$ & $0,57^{\mathrm{a}}$ & $0,45^{\mathrm{b}}$ & $0,33^{\mathrm{b}}$ \\
SK Tercerna $(\mathrm{kg} / \mathrm{e} / \mathrm{h})$ & $0,30^{\mathrm{b}}$ & $0,46^{\mathrm{b}}$ & $0,62^{\mathrm{b}}$ & $0,78^{\mathrm{a}}$ \\
\hline Keterangan: Nilai dengan superskrip yang berbeda dalam baris yang sama berbeda nyata
\end{tabular}

Keterangan: Nilai dengan superskrip yang berbeda dalam baris yang sama berbeda nyata $(\mathrm{P}<0,05)$.

Protein tercerna tertinggi pada sapi yang mendapat ransum D. Hal ini berhubungan dengan ransum yang diformulasi dapat meningkatkan palatabilitas ransum sehingga konsumsi ransum menjadi tinggi. Meningkatnya konsumsi ransum akan berdampak pada meningkatnya konsumsi protein, dengan demikian dapat meningkatkan protein tercerna. Meningkatnya protein tercerna dapat berdampak pada meningkatnya pertumbuhan yang diikuti dengan tingginya pertambahan berat badan.

Rerata bahan organik tercerna pada sapi yang mendapat ransum $\mathrm{A}$ adalah $2,11 \mathrm{~kg} / \mathrm{e} / \mathrm{h}$. Sapi yang mendapat ransum B, C dan D berturut-turut adalah 3,52 $\mathrm{kg} / \mathrm{e} / \mathrm{h}, 4,13 \mathrm{~kg} / \mathrm{e} / \mathrm{h}$ dan $4,55 \mathrm{~kg} / \mathrm{e} / \mathrm{h}$. Hasil sidik ragam menunjukkan perlakuan yang mendapat daun sengon laut secara statistik berbeda nyata $(P<0,05)$ meningkatkan bahan organik tercerna dibanding dengan perlakuan tanpa daun sengon laut.

Hasil berganda Duncan menunjukkan perlakuan B, C dan D secara statistik berbeda nyata $(\mathrm{P}<0,05)$ dibanding dengan perlakuan $\mathrm{A}$. Bahan organik tercerna pada perlakuan B nyata $(\mathrm{P}<0,05)$ dengan perlakuan $\mathrm{C}$ dan $\mathrm{D}$. Sedangkan pada perlakuan $\mathrm{C}$ dan $\mathrm{D}$ tidak nyata $(\mathrm{P}>0,05)$.

Rataan bahan organik tercerna tertinggi pada perlakuan D yaitu: 4,55 $\mathrm{kg} / \mathrm{e} / \mathrm{h}$. Tingginya bahan organik tercerna pada perlakuan $\mathrm{D}$, dikarenakan daun sengon laut $20 \%$, mampu meningkatkan konsumsi nutrien ransum yaitu bahan kering dan serat kasar serta meningkatkan kecernaan bahan kering dan serat kasar. Meningkatnya konsumsi bahan kering dan serat kasar dapat pula meningkatkan bahan organik tercerna.

\section{Simpulan}

Hasil penelitian dapat disimpulkan bahwa pemberian daun sengon hingga $20 \%$ dalam ransum dasar rumput panah dan daun angsana mampu meningkatkan kecernaan, BK 72,1\%, PK 82\%, SK 69\%, BO 78\%.

\section{Pustaka}

Deptan. 2011. Nutrisi dan Teknologi Pakan. Departemen Pertanian dan Pengembangan. Balai pengkajian Teknologi Pertanian. NTB.

Khoerunnisa. 2006. Studi komparatif metabolisme nitrogen antara domba dan kambing lokal. Skripsi. Fakultas Peternakan. Institut Pertanian Bogor, Bogor.

Orskov, E.R. And M. Ryle. 1990. Energy Nutrition inRuminant. Elsevier Appl. Sci. London.

Riwu Kaho. 2012. Blog Akademik-Ilmu Makanan Ternak. Undana. Kupang

Sampurna IP Suatha IK. 2010. Pertumbuhan Alometri Dimensi Panjang dan Lingkar Tubuh Sapi Bali Jantan. Jurnal Veteriner. XI(1): 46 - 51.

Sio, S. 2016. Pemanfaatan Air Rebusan Kulit Kayu Santen (Lannea coromandilica) untuk Meningkatkan Pertumbuhan Sapi Bali Jantan. Disertasi. Denpasar: Universitas Udayana.

Steel, R. G. D. and J. H. Torrie. 1986. Principles and Procedures of Statistic McGaw - Hill Book Co. Inc., New York.

Sutardi, T. 1995. Peningkatan Produksi Ternak Ruminansia melalui Amoniasi Pakan Serat Bermutu Rendah, Defaunasi dan Suplementasi Sumber Protein Tahan Degradasi dalam Rumen. Laporan Penelitian Hibah Bersaing I/4 Perguruan Tinggi Tahun Anggaran 1995/1996. Fapet IPB.

Putri, E. dan Marsetyo. 2006. Pengaruh penambahan daun lamtoro dan daun gamal terhadap konsumsi, subtitusi dan kecernaan pakan pada domba betina yang mendapatkan pakan dasar jerami jagung. J. Agroland. 13(12): 209-213.

Toelihere, M.R. 2003. Increasing the Success Rate and Adaptation of Artificial Insemination for Genetic improvement of Bali Cattle. ACIAR Proceedings. No 110. 48-53. 